\title{
Gene patent study drowned as OTA sinks
}

Washington. A long-awaited Office of Technology Assessment (OTA) report setting out options for the US Congress on the patenting of human genes will never see the light of day if, as expected, the OTA closes down for good on 30 September.

But two chapters from the original report - on ethics and on technology transfer within the human genome project - will be published next month, as OTA staff scramble to get out what they can before the agency shuts its doors.

The OTA study of the patenting of human DNA sequences began in March 1993 and was originally due to be completed in the summer of 1994. It was requested by Senators Mark Hatfield (Republican, Oregon), Edward Kennedy (Democrat, Massachusetts) and Dennis DeConcini (Democrat, Arizona), after Hatfield had threatened to push for a total moratorium on the patenting of such sequences.

But the issue became less of a priority for Hatfield in the spring of 1994, when the Patent and Trademark Office rejected patent applications by the National Institutes of Health (NIH) for fragments of human DNA sequences (cDNAa), and the $\mathrm{NIH}$ stated that it would not appeal against the decision. The OTA board consequently failed to push through the report last sum- mer, officials say, while the victory of the Republican party in the congressional elections, which put in doubt the future of the OTA, pushed publication back further.

Robyn Nishimi, staff director in charge of the project, has now left the OTA, to work on a Clinton administration investigation into the so-called Gulf War Syndrome. She refused to comment on the project's status.

But Denise

Dougherty, a divisional director at OTA, said that two sections of the report would be published next month as briefing papers. The technology transfer issue is of continuing interest to Congress, she said, while

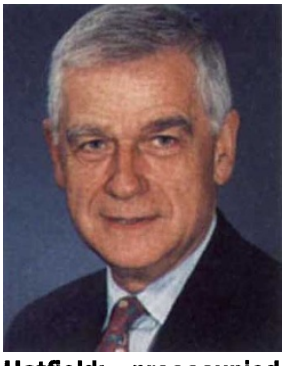

Hatfield: preoccupied with patent ethics.
Hatfield retains his interest in the ethics issue. But the core of the original project on patenting, and policy options for Congress to consider - will not be published.

Rebecca Eisenberg, a law professor at the University of Michigan and member of the panel convened by OTA to advise it on gene patenting, says the application of the existing patenting system to gene patents "will probably sort itself out over time". She believes that no change in the law is needed.

But Jeremy Rifkin, a critic of the biotechnology industry who recently convened a group of US religious leaders to criticize gene patenting on ethical grounds, said it was "ironic" that the report would not appear when "there is more pressure than ever for Congress to define what is patentable and what is not".

The ignominious fate of this study will be shared by many others at the OTA, despite the efforts of its remaining staff. "It's remarkable how hard our staff are working," says Peter Blair, assistant director of the office. "We expect to finish 30 reports before 30 September." About 50 of OTA's 200 staff have left since the beginning of the year.

When it resumes business in September, the House of Representatives will get one last chance to rescue OTA. Amo Houghton (Republican, New York) will put forward a motion to return the Legislative Branch appropriations bill to conference, on the grounds that it does not reflect the House position on the OTA (see Nature 375, 711; 1995).

But Robert Walker (Republican, Pennsylvania) says: "I don't hear many people saying they think that resolution will pass."

Colin Macilwain

\section{Last-minute lifeline for Princeton Tokamak tests}

Washington. The US Senate has thrown a desperately needed lifeline to the Princeton Plasma Physics Laboratory (PPPL) in New Jersey, raising hopes that the fusion laboratory will obtain the money needed to continue operating its Tokamak Fusion Test Reactor (TFTR), the main magnetic fusion facility in the US.

An appropriations bill amendment passed on the Senate floor would allow the Department of Energy (DoE) to spend $\$ 56$ million next year to keep TFTR going - provided the department can find the money without cutting other research programmes, for example, by reducing general administrative expenses.

Physicists at PPPL are now banking on the department to make a case to appropriators that it can come up with the money, says Dale Meade, deputy director of the laboratory.

Anne Davies, head of the fusion office at DoE, says: "All of us would very much like to continue to run TFTR. But where we get the money from is problematic." Substantial administrative savings have already been factored into the budget proposals of both the administration and the Congress, she points out.

In February, the administration asked for $\$ 360$ million for magnetic fusion research in the next financial year, which starts on 1 October. The House of Representatives has allowed \$229 million (see Nature 375,$622 ; 1995$ ) and the Senate

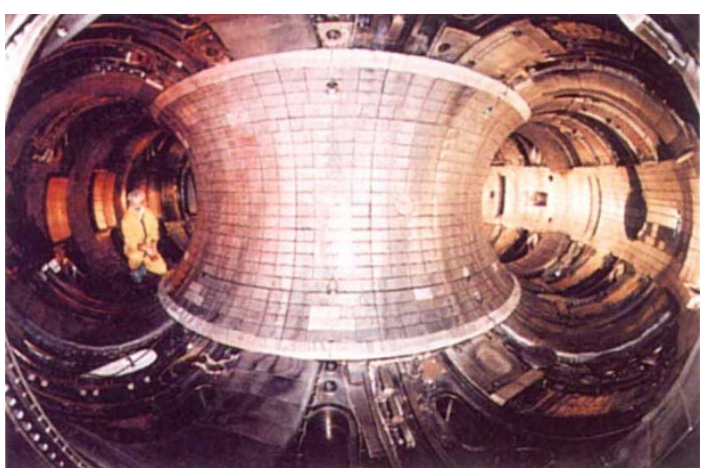
Princeton Plasma Physics Laboratory: fusing budgets to keep fusion feasible.

\$225 million, as well as the permission to spend another \$56 million on TFTR.

House and Senate appropriators will confer on 19 September to finalize the Energy and Water appropriations bill. Before then, DoE will appeal, asking them for up to $\$ 320$ million for magnetic fusion, and setting out its revised priorities.

For example, the department will drop its plan to build a new Tokamak Physics
Experiment (TPX) at PPPL, and will continue with TFTR instead. The department's revised position, and the delegates' response to it, will seal TFTR's fate.

Recent results from the reactor have addressed the problem of confining plasma in the tokamak by changing the current flux distribution therein. The results "could halve the size and cost" of a commercial tokamak reactor, says Steve Dean of Fusion Power Associates, a fusion advocacy group.

Meanwhile, DoE is seeking to redefine the US contribution to the International Thermal Experimental Reactor (ITER), the other main item in the magnetic fusion budget. At an ITER council meeting last month, the other international partners flatly rejected the idea, proposed recently in an influential report to the US government (see Nature 375,713 ; 1995), that they should enter negotiations to reduce the scope and cost of the project by two-thirds.

Whatever the final US budget figure for fusion, Davies says that her office will reshape its ITER contribution - in design, research, and basic physics to support the project - in such a way that the partners will accept that it is still contributing "a fair share of the effort".

Colin Macilwain 